\title{
Role of information technology \& the future of librarianship
}

\author{
V.N. Kale \\ Assistant Librarian, Dept. of Library science, Shrisant Shankar Maharaj College of Agriculture, Pimpalkhuta, Maharashtra, India \\ *Corresponding Author: V.N. Kale \\ Email: vaishalishilankar@gmail.com
}

\begin{abstract}
There is a growing concern by scholars in the field of library and Information science on the way technology is gradually taking over certain jobs performed by librarians and Information professionals. This may be the reason why many of the scholars have submitted that the discipline of librarianship may cease to exist in a couple of years if nothing is done to solve the problem. In the light of this, this article seeks to identify ways in which technology has taken over certain aspects of the field of librarianship with the aim of proffering solutions and identifying other means in which the $21^{\text {st }}$ century librarian can make himself relevant especially with the current dearth of employment opportunities. libraries, appear to be facing a very perilous predicament. Two of their major job responsibilities, developing subject collections and providing face-to-face reference service, are in rapid decline. Budget cuts, publisher packages for books and a transition to cost-per-use evaluations for journal subscriptions all clearly diminish the need for active collection development. Meanwhile, because of changes in information gathering habits, users increasingly approach reference librarians as a last resort. In addition, there seems to be a growing inclination among library administrators to question the importance of subject librarians in branch libraries. This is due to the well known fact that users have come to rely completely on electronic databases, notably Google and Google Scholar, and electronic journals.
\end{abstract}

Keywords: Information technology, Libraries, librarians and librarianship.

\section{Introduction}

Librarians were seen as keepers and custodians of books. This perception also affected the image of the library, this was because many people saw the library as a room with stacks of books where individuals particularly students who wanted to read beyond the scope of what they were taught in class found shelter. No wonder, the field was regarded as library science and not library and Information science or library and Information technology as we have it recently. The invention of computers by Charles Babbage and other technologies such as printing press by Johannes Gutenberg gave a face lift to libraries, librarians and librarianship in general. As a result of this, many people from other disciplines. In centuries gone by, librarians were seen as keepers and custodians of books. This perception also affected the image of the library, this was because many people saw the library as a room with stacks of books where individuals particularly students who wanted to read beyond the scope of what they were taught in class found shelter. No wonder, the field was regarded as library science and not library and Information science or library and Information technology as we have it recently. The invention of computers by Charles Babbage and other technologies such as printing press by Johannes Gutenberg gave a face lift to libraries, librarians and librarianship in general. As a result of this, many people from other disciplines began to minor in librarianship having seen the hidden potentials in the field. Libraries also in an attempt to respond to change and growth based on the fifth law of librarianship introduced the use of computers and other technologies into their day-today operations. Therefore, operations such as acquisition, cataloguing and classification etc shifted from the manual method to the automated method. The introduction of technology also brought about the development of certain concepts such as e-resources, e-libraries, digitalization etc.
However, Since the world generally operates on the principle of double-sidedness, there is a growing concern that technology has taken over the activities of librarians. This situation seems worrisome because, in the next century, librarians may find themselves losing their grounds in the current job market. In his opinion, Galeon (2017), citing Stephen Hawking opined that intelligent machines are taking over jobs. He further noted that it may only be a matter of time before humanity is forced to 2 leave the earth in search of a new home. He puts the time frame for this as 30 years but with recent happenings it seems the time frame is less than what was proposed.

\section{Methodology}

This study is based on the review of primary and secondary literature such as journals, internet articles, conference proceedings and seminar papers.

\section{Conceptual Framework Technology}

Technology is the application of techniques, systems, processes and skills to solve complex human challenges and problems. Fernald (2014) defined the term as the "Ability to convert society's resources (labor and capital) into output (goods and services that we value)". In his own view, Thiel (2014) defined the term as "any new and better way of doing things". Arthur (2009), sketches out three out three conceptions of technology which are: 1) "Technology as a means to fulfill a human purpose. As a means, a technology may be a method or process or device... Or it may be complicated... Or it may be material... Or it may be nonmaterial. Whichever it is, it is always a means to carry out a human purpose." 2) "Technology as an assemblage of practices and components." 3) Technology as the entire collection of devices and engineering practices available to a culture." In the field of librarianship, any process or 
technique that makes library operations faster is known as information technology. Information technology can be defined therefore as any form of technology that speeds up the rate at which information is created, edited, disseminated and stored for future usage. In other perspectives, the term could be defined as the application of computers and other devices such as emails, printers, faxes and scanners in the acquisition, processing and storage of information. From a scholarly perspective, information technology can be defined as recently it is stated by Tan et al. (2009) as application of Information and Communication Technologies tools including computer network, software and hardware required for internet connection.

\section{Technology and Libraries}

The changes brought about by advances in technology with particular reference to information technology have been so extensive that it is difficult to assess their total effect, but is clear that libraries are in the state of fundamental transformation. The influx of information technologies in library and information management has created divergent schools of thoughts. One school of thought aligns itself with the short run perspective, while the other school of thought aligns itself with the long run perspective. The short run perspective believes that the application of information technology in libraries has made library operations easier, faster and more efficient. The short run perspective also believes that the application of information technology also eliminates drudgery and repetitive work. Although, the long run perspective believes all the assumptions of the short run perspective, however it differs in its own view because it examines the human factor. A task performed by 5 individuals in the manual approach are now been carried out by just an individual in the automated approach.

\section{Components of ICT in Libraries}

The ICT facilities that are expected in academic library include computer hardware facilities (computers, scanners, printers, UPS, and power point projectors), computer software resources (online databases, CD-ROMs, library application software, Internet connectivity and storage media), audio-visual media/equipment (satellite connection, radio, television, audio tapes, video tapes, DVD/VCD, digital cameras and photocopiers) and communication media (telephone intercom and GSM). Adekunle, Omoba and Tella, (2007) also categorised these facilities by medium into five groups as follows: computing facilities and services; film/tape-based facilities microfiche reader, micro card reader, microprint reader, slide projector, reel to reel recorder, tape recorder, video machine etc; reproduction facilities photocopying machine, duplicating machine etc; telecommunication facilities telephone, GSM, telex, telegram, fax machine, satellite etc; broadcasting facilities radio, television, cable transmission (Adebowale, Okiki and Yakubu, 2013). Adekunle and Olorunisola (2006). Although information technology is a standalone concept, there are other components associated and conjoined with it. Islam and Islam (2006) have identified some of these as follows:
1. Software technology:- This has to do with the development of computer programs that could aid library operations. Softwares used in library operations include: Microsoft packages, tinlib, Alice for Windows etc. Given that the main mission of libraries is to offer equality of access to information for every citizen, then why not be a trendsetter in digital use and implement more emerging technologies? As Mogens Vestergaard, Manager of Library and Citizen Service at Roskilde Libraries in Denmark emphasizes in our interview here, "it is the library's obligation to be at the edge of different uses of culture and uses of technology".

2. Media usage and development:- This has to do with managing information resources available in digital formats such as CDs, projectors, microfiches etc.

3. Artificial intelligence:- This entails the development of machines to emulate human qualities such as learning, reasoning and teaching.

4. Microchips: these are technologies that contain silicons and other electronic components. They are usually used to protect and secure library materials from been stolen.

5. Workstations: these are specialized computers that help to distribute large amounts of data from a central source known as a server to other computers within the same network.

6. Emails and hypertext: e-mails (electronic mails) are messages sent over the Internet. They are usually used for current awareness and selective dissemination of information. Hypertext on the other hand is links which serve as pathways to other sources of information.

\section{Uses of Information Technologies in Libraries}

Information technologies perform a variety of functions. These include the following: Cataloguing and classification: the invention of information technology has made the process of organizing knowledge faster. The introduction of computer had made it easier for the formation of Union catalogues.

1. Indexing and Abstracting services:- In the place of the manual system of capturing important keywords in a document, computer programs are now been used to perform this tasks. All that has to be done is to import the document into the software and the essential keywords are highlighted.

2. Database Management:- Database management softwares are been employed to manage user information. Instead of the manual system of capturing the particulars of library users, databases are now been created to capture it.

3. Current Awareness Service:- This service has to do with creating awareness about library products and services. It entails bringing to the notice of library patrons new materials available in the library. The invention of information technology has made this system earlier because library users no longer have $o$ be present physically before they know materials available in the library. But e-mails can now be sent by library staff to 
them. This makes them access library materials right from the comfort of their homes.

\section{Benefits of Information Technology in Library services}

Information and communication technology is the application of technologies consisting of hardware, software, network and media for collection, storage processing transmission and presentation of information in vocal, textual, pictorial and multimedia formats, (Igwe, 2011). ICT is a term used in the library to refer to application of computers and other technologies to library practices such as acquisition, storage, organization and dissemination of information. The world has become a global village and with ICT, many library users now have access to vast sea of information, without necessarily investing much time or energy. The process of generally and distributing information is now being facilitated through the use of ICT Without mincing words, information technology has aided the growth of libraries in many ways. Reiterating the importance of ICT to library services, Mosuro (2000) has this to say: "Over the years, advances in the area of IT have offered Library and Information Centres more efficient ways of acquiring, organizing, storing and disseminating information. New Information Technologies are becoming an integral component of and have the potential of changing the status quo of libraries and librarianship. Computers as well as other information technologies have come to play prominent roles in information management. It is unthinkable that any academic library can function effectively without the appropriate use of IT." Vijayakumar and Vijayan (2011) have listed some of the benefits to include the Without mincing words, information technology has aided the growth of libraries in many ways. New Information Technologies are becoming an integral component of and have the potential of changing the status of libraries and librarianship. Computers as well as other information technologies have come to play prominent roles in information management. It is unthinkable that any academic library can function effectively without the appropriate use of IT."

\section{Insufficient funds for maintenance ICT equipments}

ICT is a generic term that refers to the technologies that are used to collect, store, edit and communicate information in various format (Raji, 2018). The use of ICT improves access to digital information, narrows down the digital divide and also improves standard of living. Adoption of ICT in libraries is a way of improving on information services provided in libraries. This is an era, when people need to access timely information with ease, and this can only be done through the application of ICT to library services. It is also a way of contributing to sustainable development of the nation, since timely and effective provision of useful information can assist in building up a society ICT as an enabling tool, assist libraries in provision of information, which is very paramount to development of the various sectors in the nation. Libraries are playing a very important role facilitating access to global information and knowledge resources, using ICT. Provision of web access to OPAC: Libraries are providing access to web-based Online Public Access Catalogue (OPAC) interfaces. The OPAC makes it easier for users to access and use information resources. OPAC is the computer form of library catalogue, to access materials in the library (Afolabi and Abidoye)

\section{Unemployment}

This is one of the core challenges of information technology. Because many libraries are shifting from the manual method to the automated method, many library staff are been laid off. Because responsibilities performed by 10 individuals are now performed by just a single machine operated by an individual. This has led to an increase in the rate for unemployment especially among young and agile librarians. However, certain jobs are beginning to emerge as a result of the invention of information technologies. This is to say that librarians especially those of the younger generation need not entertain any fear as regards employment. A growing number of librarians are coming out of library school and can't find professional work, or full-time work. The promise of "there will be a lot of retirements soon so jobs will open up" has been heard for a long time, and often, when that time comes, full-time jobs become multiple part-time jobs or are eliminated completely. Likewise, many mid-career part-time librarians, as well as people entering the profession from other fields, struggle to find work in an uncertain economy. As the unemployment and underemployment issue worsens, what can organizations like ALA, as well as library graduate programs, do to tackle this issue? Overall, there are more librarian candidates applying for coveted full-time professional jobs than jobs actually available to those candidates, particularly in areas with a library school, making competition for jobs remarkably tough regardless of how much experience or skills a candidate may possess. Additionally, with an MLIS, many librarians be seen as overqualified for paraprofessional work, and hiring committees may assume that librarians with an MLIS may not stick around for long once a better job comes along. A recent article in Public Libraries Online describes how parttime jobs are the new norm for librarians. Therefore, those candidates must do what they can to survive while obtaining that perfect job, which may mean using library skills in a nonlibrary setting, taking up internships and volunteer work, or finding other ways to generate income until a paying library job comes along.

\section{Conclusion}

From the foregoing, this article has been able to identify the nexus between information technology and its impacts on the field of librarianship. However, in order to ensure that the field of librarianship does not go into extinction, all hands must be on deck. Apart from that, the following must be put into place in order to bridge the identified gaps College students trust information they get from libraries, and they trust the information they get from search engines. The survey revealed that they trust them almost equally, which suggests that libraries have no monopoly on the provision of information. Most college students are very familiar with 
search In a world where the sources of information and the tools of discovery continue to proliferate and increase in relevance to online information consumers, the brand differentiation of the library is still books. The library has not been successful in leveraging its brand to incorporate growing investments in electronic resources and library Webbased services. Can the brand be expanded or updated to be more relevant, to be more than books? Libraries must work collectively to "rejuvenate" the brand. It is not simply about educating students about the library and its physical and electronic resources. Trying to educate consumers whose habits and lifestyles are changing and have changed seldom works. It doesn't work for companies and it probably won't work for libraries. Rejuvenating the "Library" brand depends on the abilities of the members of the broad library community to redesign library services so that the rich resources - print and digital - they steward on behalf of their communities are available, accessible and used. Rejuvenating the brand depends on reconstructing the experience of using the library.

While the need for localised points of distribution for content that is no longer available in just physical form is likely to become less relevant, the need for libraries to be gathering places within the community or university has not decreased. The data are clear. When prompted, information consumers see libraries 'role in the community as a place to learn, as a place to read, as a place to make information freely available, as a place to support literacy, as a place to provide research support, as a place to provide free computer/ Internet access and more. These library services are relevant and differentiated. Libraries will continue to share an expanding info-sphere with an increasing number of content producers, providers and consumers. Information consumers will continue to self-serve from a growing information smorgasbord. The challenge for libraries is to clearly define and market their relevant place in that info-sphere their services and collections both physical and virtual. engines, email and instant messaging.

As more content becomes directly accessible via search engines and to handheld devices, familiarity with more and different types of digital content is likely to increase. Will trust continue to increase too?:

1. Libraries must constantly train their staff to be IT compliant. This will reduce the rate at which their jobs are given to other individuals not within the purview of librarianship. These include database management, web design, software management and installation.

2. Librarians in training must be exposed to entrepreneurial opportunities in the field of library and Information Science. Such opportunities include indexing and abstracting, research assistance, research analysis, database management etc.

3. Librarians must not depend on only what they learn in school. Their tentacles of knowledge must spread to other disciplines. Librarians should be "Jack of all trades, master of All". In essence, they should have certain amounts of knowledge on all discipline of human endeavour.

4. Leveraging of information retrieval skills. Librarians must constantly update their information retrieval skills. The skills of yesterday might not suffice for today's challenges. Since information management is one that gets complex day-by-day, librarians must update their skills and be able to sieve the "wheat "from the "shaft" and it will make librarians knowledge creators rather than knowledge consumers.

5. This will help to increase the value of libraries, librarians and librarianship altogether effective lobbying and advocacy is necessary in order to raise funds to maintain information technologies.

\section{Conflict of Interest}

None.

\section{Source of Funding}

None.

\section{References}

1. Adekunle, Omoba and Tella, (2007)

2. (Adebowale, Okiki and Yakubu, 2013)

3. Adekunle and Olorunisola (2006)

4. Arthur W.B. "Zero to One: Notes on How to Build the Future" Fernald, J. (2014). "Technology and the American Economy: Or, What's the New Normal". Paper presentation at policy conference, Federal Reserve Bank of San Francisco. 2009

5. Galeon D. (2017). "The Point of no Return". https://www.weforum.org/agenda/2017/11/why-stephenhawking-thinks-aimight-replace-

humans?utm_content=bufferb8243\&utm_medium=social\&utm _source=facebook.com\&utm_campaign=buffer. Retrieved

February 24, 2018.

6. Islam $\mathrm{S}$, Islam $\mathrm{N}$. "Information and Communication Technology (ICT) in Libraries: A new dimension in Librarianship". Asian Journal of Information Technology, 2006;5(8):809-17.

7. Mosuro. "Potential Impact of New Information Technologies on Libraries and the Library User, Library Automation for the Information Age: Concepts, Technologies and Strategies". 2000

8. Randniecki T. "Study on emerging technology librarians: How a new library position and its competencies are evolving to meet the technology and information needs of libraries and their patrons". 2013.Retrieved from http://creativecommons.org/licenses/by/3.0/

9. Tan, KS, Chong SC. "Internet-based ICT adoption: Evidence from Malaysian SMEs." Industrial Management Data Syst 2009;109(2):224-44.

10. Thiel P. (2014). "Zero to One: Notes on How to Build the Future".

11. Vijayakumar A. Vijayakumar S.S. "Application of Information technologies in Libraries: an overview". Int J Digit Libr Stud 2011:2250-1142

How to cite: Kale VN. Role of information technology \& the future of librarianship. IP Indian J Libr Sci Inf Techno 2020;5(2):79-82. 